\title{
REGENERATION OF FIVE COMMERCIALLY-VALUABLE TREE SPECIES AFTER EXPERIMENTAL LOGGING IN AN AMAZONIAN FOREST ${ }^{1}$
}

\author{
Albertina Pimentel Lima ${ }^{2}$, Odilon Pimentel de Lima², William Ernest Magnusson², Niro Higuchi² e \\ Francisco Quintiliano Reis ${ }^{3}$
}

\begin{abstract}
This study investigated the regeneration variation of five commercially valuable tree species in relation to different intensities of felling in fourteen 4-ha plots in an area under experimental forest management. This experiment was carried out in a typical Amazonian tropical forest sample on "terra-firme," in Manaus (AM). Plots were logged 7 and 8 years (1987 and 1988), or 3 years (1993) before the study. All trees with height greater than $2 \mathrm{~m}$, and diameter at breast height (DBH) smaller than $10 \mathrm{~cm}$ were measured. Only Aniba hostmanniana, Ocotea aciphylla, Licaria pachycarpa, Eschweilera coriacea and Goupia glabra were sufficiently common for individual analyses. These species have high timber values in the local market. Eight years after logging, the species responded differently to logging intensities. The numbers of individuals of Goupia glabra and Aniba hostmanniana were positively related to the intensity of logging, while Ocotea aciphylla, Licaria pachycarpa, and Eschweilera coriacea showed no statistically significant response. In the most recently (1993) logged areas, Goupia glabra and Aniba hostmanniana had higher numbers of individuals than the control plots.
\end{abstract}

Key words: $\quad$ Forest management, forest dynamics and natural regeneration.

\section{REGENERAÇÃO DE CINCO ESPÉCIES FLORESTAIS DE VALOR COMERCIAL PÓS-CORTE SELETIVO DE MADEIRA NA AMAZÔNIA CENTRAL}

\begin{abstract}
RESUMO - Foi investigada a variação na densidade de regeneração de cinco espécies arbóreas de valor comercial, em relação a diferentes intensidades de corte seletivo de madeira em 14 parcelas de 4 ha, em uma área de corte experimental em floresta tropical úmida de terra-firme da região de Manaus (AM). A redução em volume de árvores em pé, de valor comercial ou não, variou de 44 para $107 \mathrm{~m} 3 / \mathrm{ha}$. As parcelas foram exploradas entre sete e oito anos (1987 e 1988) ou três anos (1993), antes do estudo. Todas as árvores com altura maior que $2 \mathrm{~m}$ e diâmetro à altura do peito (DAP) menor que $10 \mathrm{~cm}$ foram medidas. As espécies estudadas foram Aniba hostmanniana (louro-amarelo), Ocotea aciphylla (louro-fofo), Licaria pachycarpa (louro-preto), Eschweilera coriacea (matamatá-amarelo) e Goupia glabra (cupiúba). Essas espécies têm alto valor no mercado local de madeira. Oito anos depois do corte seletivo, as espécies responderam diferentemente às intensidades de corte. $\mathrm{O}$ número de indivíduos das espécies Goupia glabra e Aniba hostmanniana apresentou correlação positiva e significante em relação à intensidade de corte, enquanto Ocotea aciphylla, Licaria pachycarpa e Eschweilera coriacea apresentaram correlações não-significativas. Nas áreas que sofreram cortes mais recentes, exploração executada em 1993, o número de indivíduos de Goupia glabra e Aniba hostmanniana aumentou, quando comparado ao das áreas-controle.
\end{abstract}

Palavras-chave: Manejo florestal, dinâmica florestal e regeneração natural.

1 Recebido para publicação em 14.8.2001. Aceito para publicação em 6.11.2002.

2 Coordenação de Pesquisas em Ecologia, Instituto Nacional de Pesquisa da Amazônia (INPA), Caixa Postal 478, 69011-970 Manaus-AM, <lima@inpa.gov.br>; ${ }^{3}$ Coordenação de Pesquisas em Silvicultura Tropical, INPA. 


\section{INTRODUCTION}

The dynamics and diversity of tropical forests are strongly influenced by natural tree falls, which make the forest appear as mosaic composed of trees of various sizes and ages (e.g. Brokaw \& Scheiner, 1989; Brown, 1993; Denslow, 1980; Whitmore, 1991). This occurs because seedlings of different tree species may achieve optimal growth under different light regimes in differently sized gaps (e.g. Canham, 1989; Clark, 1990; Whitmore, 1991). Therefore, studies of gap dynamics and effect of edges are fundamental to understand the causes and possible direction of forest succession and can be important indicators of sustainability of tropical forest management systems (Johns, 1997; Whitmore, 1991). However, selective logging causes alterations that result in changes in penetration of sunlight into the understory, generally even far from the gaps. The gaps formed during logging affect the distribution and growth of many species, and since they can favor the regeneration of species of non-commercial value, this may reduce the value of residual forest in future logging cycles (Johns, 1997; Vieira, 1995).

In 1985, a project was initiated in a forest management station of the Instituto Nacional de Pesquisas da Amazônia to evaluate the effects and benefits of commercial timber extraction in fourteen 4-ha plots subjected to projected intensities of logging that varied from $35 \%$ to $65 \%$ of total volume. In that area, Magnusson et al. (1999) found no reduction in the total potential value of the established regeneration in areas of selective logging, as compared to the control areas. Magnusson et al. (1999) studied all the species, but commercial operations can be jeopardized if the number of species is extremely high and the harvest of some species is small. Therefore, this study aimed to evaluate the individual responses of the five most common desirable trees in the established regeneration in the same area the experimental logging was studied by Vieira (1995) and Magnusson et al. (1999).

\section{MATERIAL AND METHODS}

The study was conducted in the Forest Management Experimental Station of the Instituto Nacional de Pesquisas da Amazonia (2 $2^{\circ} 37^{\prime} \mathrm{S}$ latitude, $60^{\circ} 11^{\prime} \mathrm{W}$ longitude), $90 \mathrm{~km}$ North of Manaus in the state of Amazonas, Brazil. The experimental design consisted of three blocks of 24 ha located on a large plateau of yellow clay Latosol (Oxisol). Five 4 ha treatment plots were distributed randomly in each block. Each block had one control (untouched forest), two plots felled in 1987, one felled in 1988, and one in 1993. Sample plots were located on plateaus, but some of them included areas with small slopes. In most cases, the slopes produced variations in altitude of less than one meter, which we believe are not large enough to affect the results. One plot felled in 1987 was not surveyed because this plot had an area with extensive slopes, and a sandy area in which temporary puddles formed in the rainy season, and this could introduce habitat variation not associated with selective logging.

Wood volume reduction which varied from 44.23 to $106.77 \mathrm{~m}^{3} / \mathrm{ha}$, was calculated from the inventories made before and after logging in a central hectare, for all trees with $d b h \geq 10 \mathrm{~cm}$ (Magnusson et al., 1999). Each plot was traversed by eight straight parallel walking trails $200 \mathrm{~m}$ long, spaced $25 \mathrm{~m}$ apart. To reduce the edge effects from neighboring plots, only the central $175 \mathrm{~m}$ of the six central trails were sampled. Individuals with $d b h \leq 10 \mathrm{~cm}$ and height $\geq 200 \mathrm{~cm}$ of each species were censused in a strip $1 \mathrm{~m}$ wide, and $1 \mathrm{~m}$ distant from the tracks. The established regeneration category was used for comparisons because smaller size classes vary seasonally and inter-annually depending on seed crops, and larger size classes had little time to recover in the 3-8 year post-logging. The species were identified based on vegetative characteristics. Subsequently, samples of species were collected and checked against specimens in the INPA Herbarium.

Only five species, Aniba hostmanniana (Nees) Mez (Lauraceae), Ocotea aciphylla (Nees) Mez (Lauraceae), Licaria pachycarpa (Meissn.) Kosterm. (Lauraceae), Eschweilera coriacea Mart. ex Berg (Lecythidaceae), and Goupia glabra Aubl. (Celastraceae) were sufficiently common for individual analyses. The effect of logging intensity was tested by simple linear regression and included only the controls with zero intensity of logging and eight plots felled in 1987/1988. The plots felled in 1993 were not included so that the effect of time since logging would not be confused with the effect of intensity of logging damage. Too few replicates were available to evaluate the effect of logging intensity on the 1993 plots, or to test for an interaction between time and intensity of logging.

The value of the wood per $\mathrm{m}^{3}$ for each species was obtained from the local timber market. Values in Brazilian 
Real currency were transformed into US dollar values at an exchange rate of $1.20 \mathrm{R} \$$ for $1 \mathrm{US} \$$.

\section{RESULTS AND DISCUSSION}

Only Aniba hostmanniana ( $\mathrm{n}=43)$, Ocotea aciphylla $(\mathrm{n}=122)$, Licaria pachycarpa $(\mathrm{n}=59)$, Eschweilera coriacea $(\mathrm{n}=213)$ and Goupia glabra $(\mathrm{n}=57)$ had commercial values in the timber markets and were sufficiently common to justify analysis.

The species responded differently to the felling intensities in plots logged in 1987/1988. The number of Goupia glabra increased with the logging intensity $\left(\mathrm{F}_{1,9}=17\right.$; $\left.\mathrm{r}^{2}=0.66 ; \mathrm{P}=0.002\right)$, but the major difference found was between controls and the logged plots (Figure 1). The values Goupia glabra were for log transformed to improve normality and homogeneity of variances. There was no significant relationship between density and logging intensity for Aniba hostmanniana $\left(\mathrm{F}_{1,9}=2.3 ; \mathrm{r}^{2}=0.21\right.$; $\mathrm{P}=0.16)$. However, the plot with reduction in wood volume of $107 \mathrm{~m}^{3} /$ ha was considered to be an outlier (Figure 1), and Aniba hostmanniana increased significantly with logging intensities when that point was excluded $\left(\mathrm{F}_{1,8}=16.8 ; \mathrm{r}^{2}=0.68\right.$; $\mathrm{P}=0.003)$. The line in figure 01 showing the relationship for Aniba hostmanniana was calculated without the outlier, represented by the open square. The densities of Ocotea aciphylla, Licaria pachycarpa, and Eschweilera coriacea were not significant $\left(\mathrm{F}_{1,9}=0.001 ; \mathrm{r}^{2}=0.01 ; \mathrm{P}=0.97 ; \mathrm{F}_{1,9}=0.02\right.$; $\mathrm{r}^{2}=0.001 ; \mathrm{P}=0.88 ; \mathrm{F}_{1,9}=1.6 ; \mathrm{r}^{2}=0.15 ; \mathrm{P}=0.24$, respectively) when related to logging intensities (Figure 1).

There was a significant increase in density of Goupia glabra ( ANOVA: $\mathrm{F}_{1,4}=27.8 ; \mathrm{P}=0.006$ ) in the plots logged in 1993 in relation to the control plots (Figure 2). Also, the density of Aniba hostmanniana increased in the plots 3 years post-felling (Figure 2), but the sample size was small and the difference was not quite statistically significant (paired t-test, $\mathrm{t}=-4.0, \mathrm{n}=6, \mathrm{P}=0.057$ ). The other three species did not differ significantly in density ( $\mathrm{P}>0.15$ in all cases) between the plots logged in 1993 and control areas (Figure 2).

In Central Amazonia, the disturbance caused by selective logging had little effect on the established regeneration of most species (Magnusson et al., 1999). In this study, selective logging did not significantly affect the density of three of the five commercially-valuable species that were most common in the established regeneration, indicating that logging had little effect on the establishment of those species. Only Goupia glabra
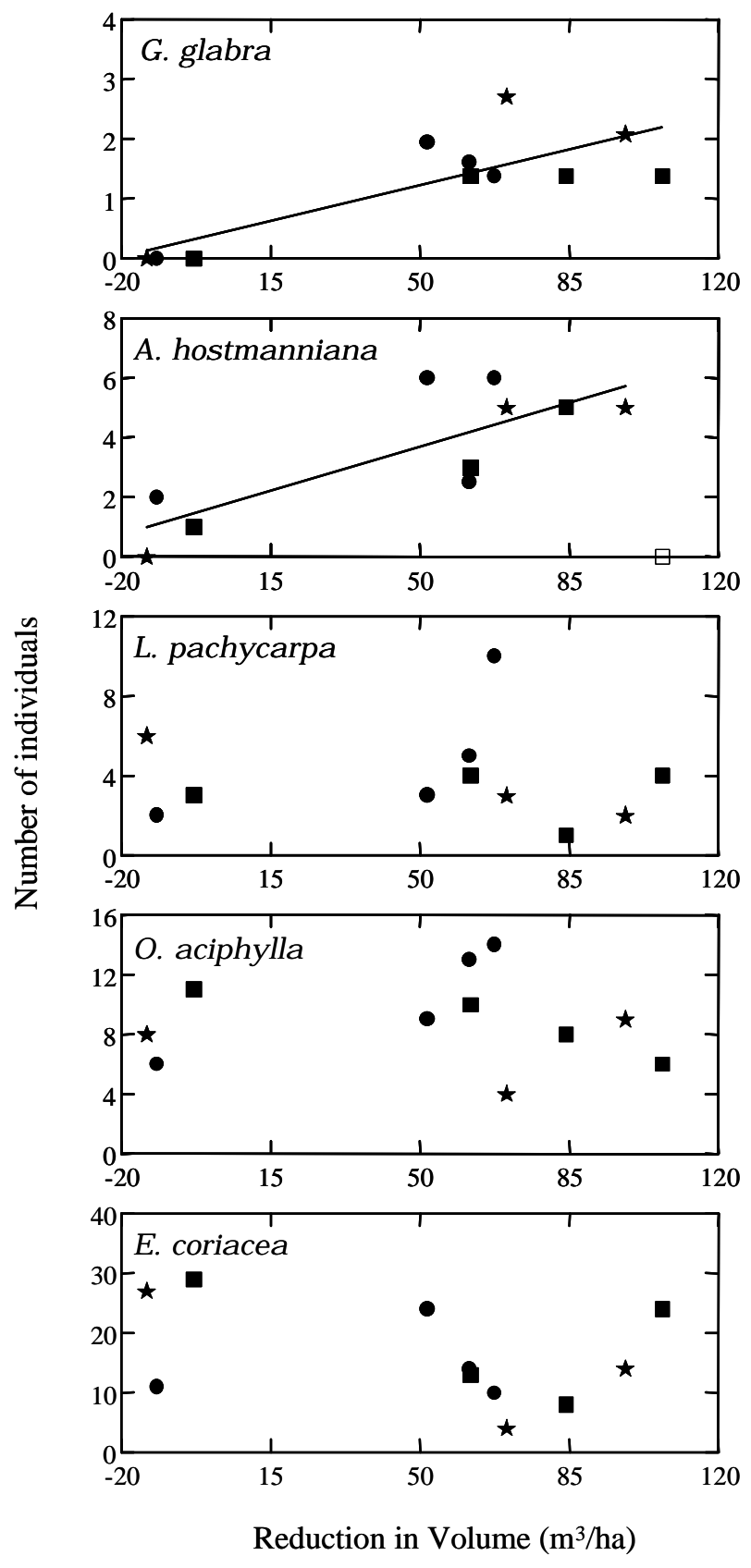

Figure 1 - Relationships between the number of individuals of each species and the reduction in wood volume of trees with $\mathrm{dbh} \geq 10 \mathrm{~cm}$. Circles represent plots in block one, squares represent plots in block two, and stars represent plots in block three.

Figura 1 - Relação entre o número de indivíduos de cada espéciee a redução no vol ume de madeira deárvores com DAP $\geq 10 \mathrm{~cm}$. Círculos representam parcelas no bloco um, quadrados representam parcelas no bloco dois e esterlas representam parcel as no bl oco quatro.

R. Árvore, Viçosa-MG, v.26, n.5, p.567-571, 2002 
(cupiúba) and possibly Aniba hostmanniana (louroamarelo), increased with logging intensity, indicating that these species could be more common in the next cutting cycle. The results of this study agree with what is known about the life history of the species. Goupia glabra is a long-lived early successional species that attains the canopy (Oldeman \& van Dijk, 1991; Whitmore, 1991). This was the only species in which density increased as much in recent-logging, 3 year post-logging, as in older regeneration, 7-8 years) post-logging. Up to 1991 , Goupia glabra was not commercially-valuable in neotropical rain forests (Whitmore, 1991). In Manaus, in 1997, this species had relatively high timber values in the local timber market, being sold for US $\$ 250 / \mathrm{m}^{3}$, while the other four species in this study, had values varying from US\$ 116 to US\$ 250/m³ (April, 1997 value). This illustrates the danger of recommending interventions such as enrichment planting or girdling (Barros \& Veríssimo, 1996; Vieira, 1995) based on current timber values. Many of the species considered to be non-commercial will be found to have a market, or other ammenity values in the near future.

Several studies abroad have shown that various climax tree species have the capacity to establish in gaps of a wide range of sizes (Central America: Brokaw \& Scheiner, 1989; Queensland: Thompson et al., 1988, Sabah: Brown \& Whitmore, 1992). Aniba hostmanniana grows better in small gaps (Oldeman \& van Dijk, 1991), and this could have caused the most intensively logged plot to be considered as an outlier. This species responded positively to moderate logging intensities.

The other species, Ocotea aciphylla. (louro-fofo), Licaria pachycarpa. (louro-preto), and Eschweilera coriacea. (matamatá-amarelo) are considered to be slow growing; therefore, a positive effect of the intensity of logging is not expected. However, these species were the most common in the established regeneration and the intensity of logging did not reduce the density of these species in recently logged or older regenerations. This indicates that they are regeneration generalists and consequently can survive in or around the large gaps resulting from selective logging. Therefore, they should be available in the next harvest cycle. As they have relatively high timber values in the local market, and in most Amazonian terra firme forests, extraction levels do not exceed 3-5 trees/ha (Johns, 1997). Selective logging based largely on these species has the potencial to be an economically sustainable activity in Central Amazonia.
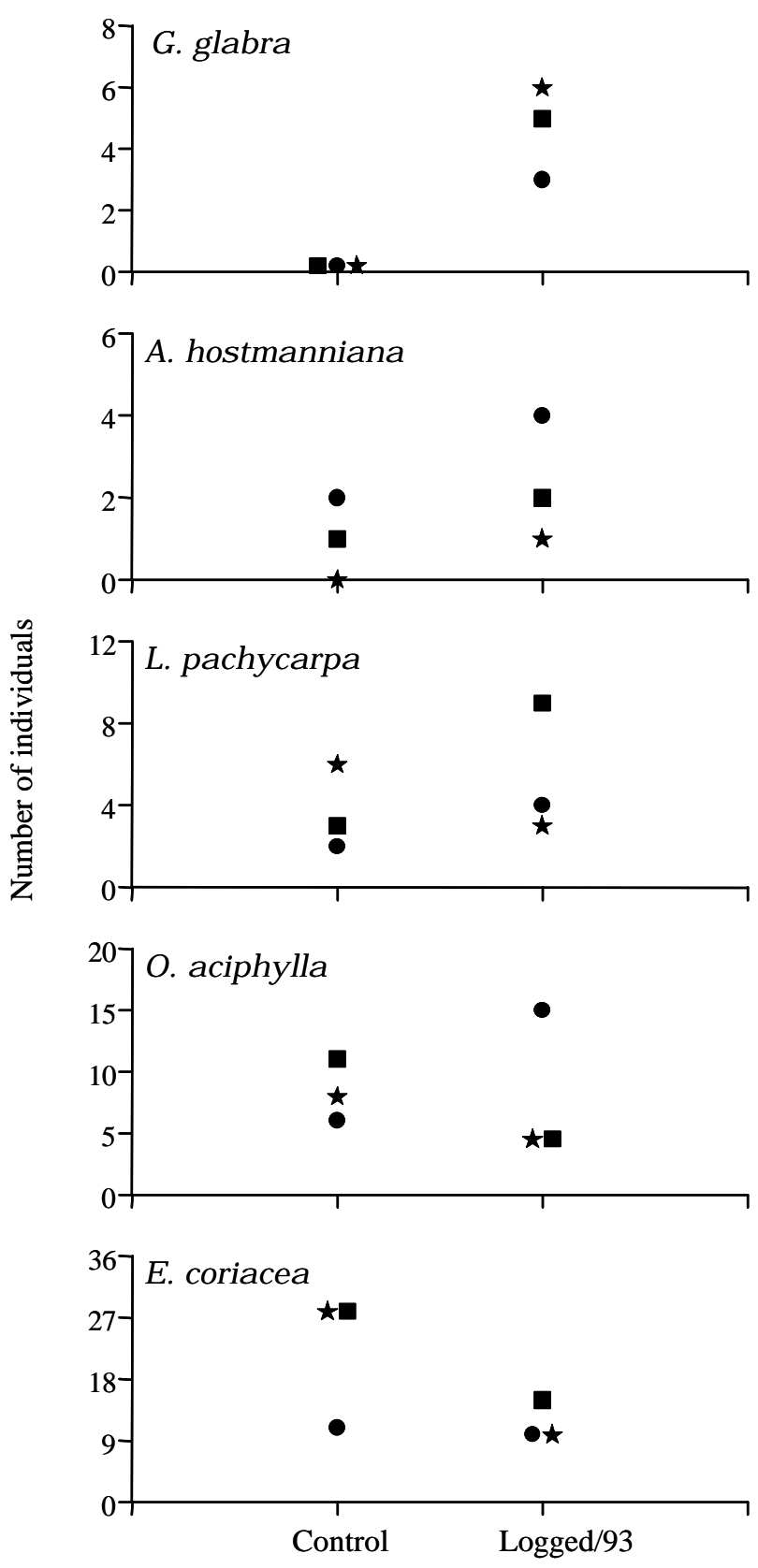

Figure 2 - Differences in the densities of trees between control plots (unlogged forest) and plots logged in 1993, three years before study. Circles represent plots in block one, squares represent plots in block two, and stars represent plots in block three.

Figura 1 - Diferenças nas densidades de árvores entre parcel as-controle (sem corte) eparcel as contadas em 1993, três anos antes do estudo. Círcul os representam parcel as no bl oco um, quadrados representamuuhhhuuyyy $=$ parcelas no bloco dois e estrelas no bloco quatro. 


\section{CONCLUSION}

- Eight years after logging, the species responded differently to logging intensities.

- The number of Goupia glabra, and possibly Aniba hostmanniana, was positively related to the intensity of logging, while Ocotea aciphylla, Licaria pachycarpa, and Eschweilera coriacea showed no statistically significant response.

- The number of Goupia glabra increased with logging intensity, but the major difference was between controls and the logged plots.

- In the most recently logged areas, Goupia glabra and probably Aniba hostmanniana increased in number of individuals, compared to the unlogged plots.

\section{ACKNOWLEDGEMENTS}

This research could not have been completed without the logistic support of all the field technicians of the EEST of the Tropical Silviculture Research Cordenation. The authors are very grateful for their support. We also thank José Ferreira Ramos for identifying the specimens in the INPA Herbarium. Financial support was provided by INPA (PPI \# 2-3530) and grants from CNPq to William E. Magnusson and Odilon P. de Lima. Logging operations of 1993 were funded by the BIONTE Project.

\section{REFERENCES}

BARROS, A. C.; VERÍSSIMO, A. A Expansão da atividade madeireira na Amazônia. Belém: IMAZON, 1996. p. 168.

BROKAW, N. V. L.; SCHEINER, S. M. Species composition in gaps and structure of a tropical forest. Ecology, v. 70, p. 538-541, 1989.

BROWN, N. The implications of climate and gap microclimate for seedling growth conditions in a Bornean lowland rain forest. Journal of Tropical Ecology, v. 9, p. $153-168,1993$.
BROWN, N. D.; WHITMORE, T. C. Do dipterocarp seedlings really partition tropical rain forest gaps?. In: MARSHALL, A. G.; SWAINE, M. D. (Eds.) Tropical rain forest: disturbance and recovery. London: The Royal Society of London, 1992. p. 369-378.

CANHAM, C. D. Different responses to gaps among shadetolerant tree species. Ecology, v. 70, p. 548-550, 1989.

CLARK, D. B. The role of disturbance in the degeneration of neotropical moist forests. In: BAWA, K. B.; HADLEY, M. (Eds.). Reproductive ecology of tropical forest plants. Paris: UNESCO, 1990. p. 291-315.

DENSLOW, J. S. Gap partitioning among tropical rainforest trees. Biotropica, v. 12 (Supplement), p. 47-55, 1980 .

JOHNS, A. G. Timber production and biodiversity conservation in tropical rain forests. United Kingdom: Cambridge University Press, 1997. p. 210.

MAGNUSSON, W. E. et al. Logging activity and tree regeneration in an Amazonian forest. Forest Ecology and Management, v. 113, p. 67-74, 1999.

OLDEMAN, R. A. A.; van DIJK, J. Diagnosis of the temperament of tropical rain forest trees. In: GOMEZPOMPA, A.; WHITMORE, T. C.; HADLEY, M. (Eds.). Rain Forest Regeneration and Management. Paris: UNESCO, 1991. p. 621- 665.

THOMPSON, W. A.; STOCKER, G. C.; KRIEDERMAN, P. E. Growth and photosynthetic response to light and nutrients of Flindersia brayleyana F. Muell., a rainforest tree with broad tolerance to sun and shade. Australian Journal of Plant Physiology, v. 15, p. 299-315. 1988.

VIEIRA, G. Dynamics of the remaining plant population in gaps after logging in the Amazon. In: MALIK, A. R. A.; NIK, A. R.; MOHAMAD, A.; SEE, L. S.; HOY, A. W. H.; CHOON, K. K. (Eds.). Forestry and Forest Products Research: proceeding of the third conference. Malaysia: Forest Research Institute Malaysia, 1995. p. 54-67.

WHITMORE, T. C. Tropical rain forest dynamics and its implications for management. In: GOMEZ-POMPA, A.; WHITMORE, T. C.; HADLEY, M. (Eds). Rain forest regeneration and management. Paris: UNESCO, 1991. p. 667-689. 